\title{
Neuron-Specific Enolase Positive Neoplastic Cells Present
}

National Cancer Institute

\section{Source}

National Cancer Institute. Neuron-Specific Enolase Positive Neoplastic Cells Present. NCI

Thesaurus. Code C60707.

An immunophenotypic test result indicating positive staining of neoplastic cells for neuron-specific enolase. 